\title{
Analysis of Challenges and Barriers of Adopting Fair Value Accounting for Real Estate Valuation in Public Listed Companies - Sri Lanka
}




\title{
Analysis of Challenges and Barriers of Adopting Fair Value Accounting for Real Estate Valuation in Public Listed Companies- Sri Lanka
}

\author{
Dissertation Submitted to the \\ University of Sri Jayewardenepura \\ as a Partial Fulfillment for the
}

Requirements of the Final Examination of the

M.Sc. in Real Estate Management and Valuation Degree

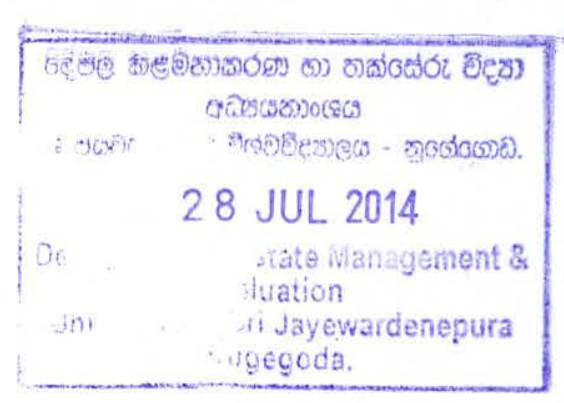

Full Name : Widana Hewage Terans Gunawardhana

Examination No : REMV/108

Registration No : 5501/FM 2010/0012

Department : Department of Estate Management and Valuation

University : University of Sri Jayewardenepura

Date of Submission :

First submission (for evaluation) : $03^{\text {rd }}$ June 2014

Second submission (corrected final report) : $28^{\text {th }}$ July 2014 


\section{Student's Declaration}

The work described in this dissertation was carried out under the supervision of Professor Kennedy D. Gunawardane. Any report on this has not been submitted in whole or in part to any University or any other Institute for another Degree /Examination or any other purpose.

W.H. T. Gunawardhana

$28^{\text {th }}$ July 2014 


\section{Supervisor's Declaration}

Hereby, I certify that Mr. Widana Hewage Terans Gunawardhana, 5501/FM2010/0012, duly completed the due corrections in the research titled "An Analysis of Challenges and Barriers of Adopting Fair Value Accounting for Real Estate Valuation in Public Listed Companies - Sri Lanka" under my supervision and recommended for the final submission.

Also it is declared that, this final report has been completed according to the instructions and suggestions made by the board of examiners.

Signature of the Supervisor Fret Dr. Kernedy D. Gunawardara

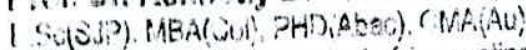

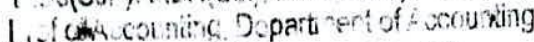

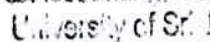

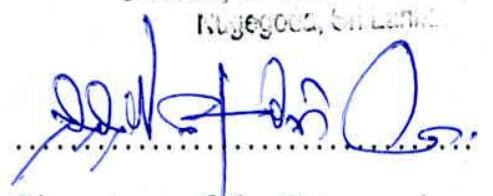

Signature of the $2^{\text {nd }}$ examiner

Signature and the official stamp of the Coordinator 


\section{Acknowledgement}

First and foremost, I wish to pay my gratitude to Prof. Kennedy .D GunawardeneDepartment of Accounting for being Supervisor to me, giving his expert guidance and greater supervision extended throughout for the success of this research.

Next but essentially, I offer my gratefulness and sincere thanks to Prof. R.G Ariyawansa Course Coordinator-Msc/PGD in Real Estate Management and Valuation, his kind guidance \& valuable advices; not only for this study but also for entire my life is invaluable. Also, Senior Lecturer Mrs. Janaki Edirisinghe-Former Head of the Department of Estate Management \& Valuation, Senior Lecturer Mrs. K.G.P.K Weerakoon for offering much advices and insights throughout my Research work and all other members of Academic Staff of the Department of Estate Management \& Valuation those who advertently, and without fail, provided learning materials and sharing a smile and a hello at times we crossed our ways, making it a pleasant infrastructure for a research work.

Also, I convey my special honor to the President of Institute of Valuers Sri Lanka, Mr. S N Wijepala who guided, encouraged and advised me specially at very critical areas throughout my research, and also I owe my adoring gratitude to the staff of ITRC, Faculty of Management Studies and Commerce, who helped numerously, so I could think towards the success of this research.

Most importantly, my Thaththa and Amma owe my loving gratitude, for giving everything I needed as respectable, caring and devoted parents. Finally my affectionate admiration to Narmada, the fiancée who did everything she can do to get succeeded this study. Indika, Tharnga and Dhanuska, the loving brothers for the patience had over my consumption of time belong to you all towards the research work and for the courage given to me throughout.

I owe you all, thank you so much!

\section{Terans Gunawardhana}

$28^{\text {th }}$ July 2014 


\section{LIST OF TABLES}

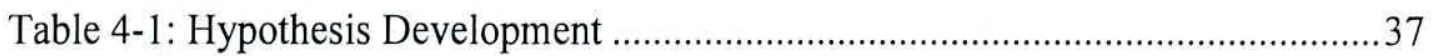

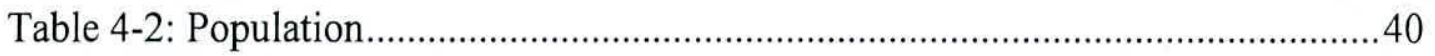

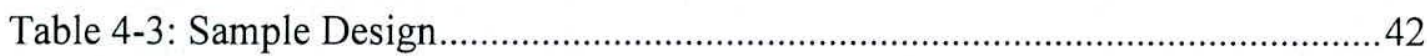

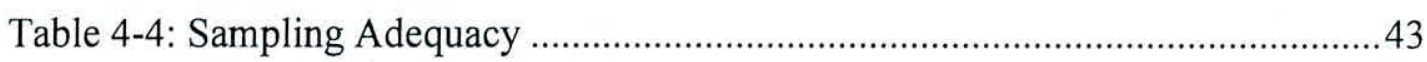

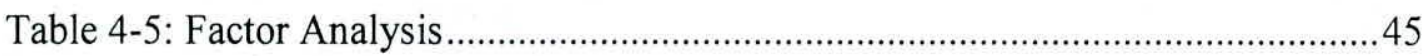

Table 5-1: Public Listed Companies in Sri Lanka .........................................................49

Table 5-2 : Sectorial classification of companies in CSE in the selected sample........51

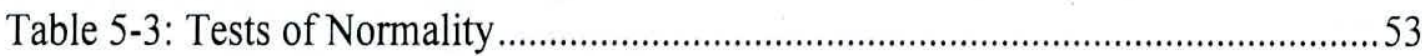

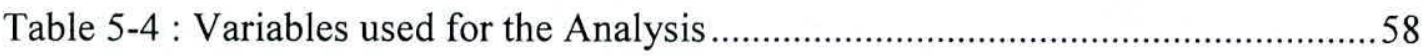

Table 5-5 : Reliability and Convergent Validity of Constructs ..................................61

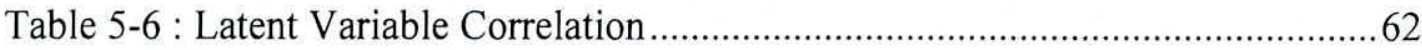

Table 5-7 : Cross Loadings for the measurement model ............................................63

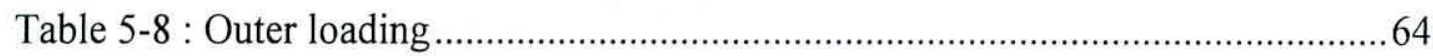

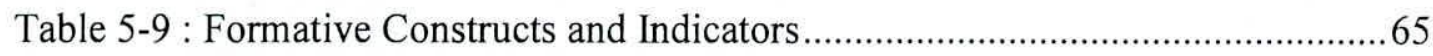

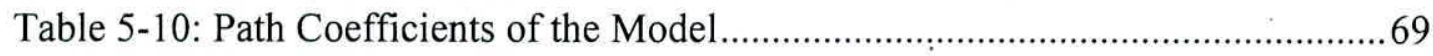

Table 5-11 : Outer weights of the Model................................................................. 71

Table 5-12 : Outer Loading (Mean, STD, T-Value) of the Model .............................. 72

Table 5-13 : Significance of Path Coefficients- (Mean, STD, T-Values) ...................73

Table 5-14 : Results of the structural model for Ha to Ho.............................................76

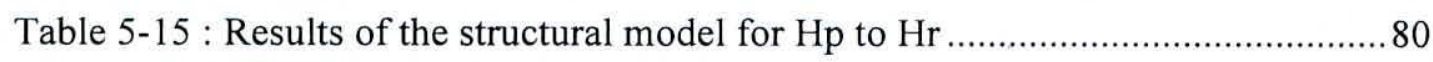

Table 5-16: Measurement for Mediating Effect of the model ....................................82 


\section{LIST OF FIGURES}

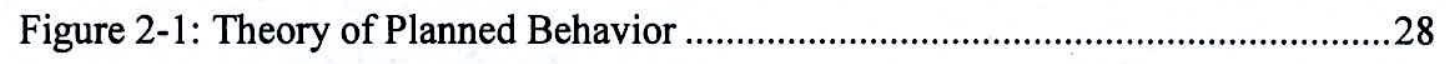

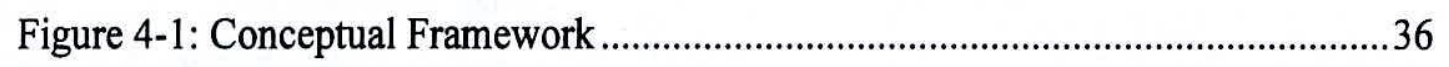

Figure 5-1:The Conceptual Framework diagram in SmartPLS Form .........................54

Figure 5-2 : Results of the structural model with path coefficients ............................68

Figure 5-3: Structural Path Significance in Bootstrapping ........................................ 70 


\section{Table of Contents}

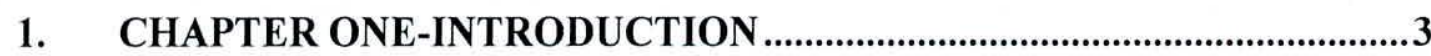

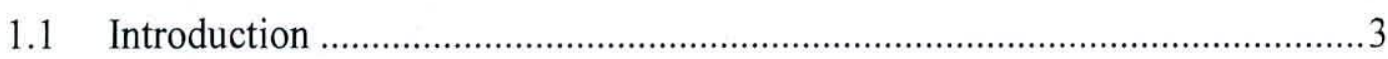

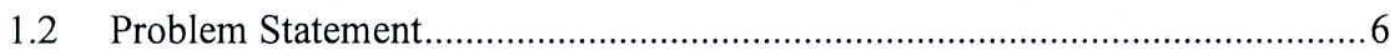

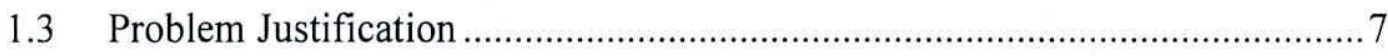

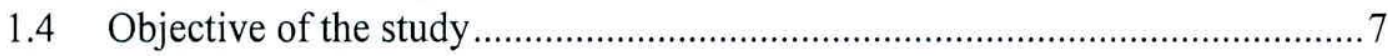

1.4.1 General Objective ........................................................................................

1.4.2 Specific Objectives........................................................................................

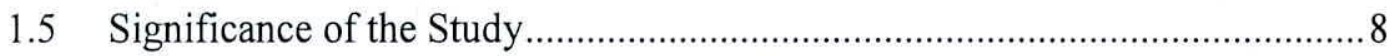

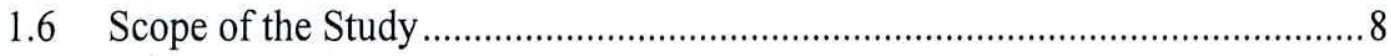

1.7 Chapter Plan of the Study .........................................................................

2. CHAPTER TWO - LITERATURE REVIEW .................................................10

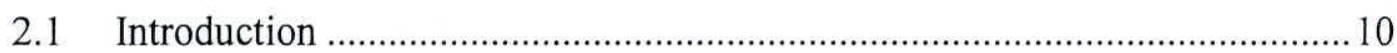

2.2 International Financial Reporting Standards (IFRSs) .................................... 10

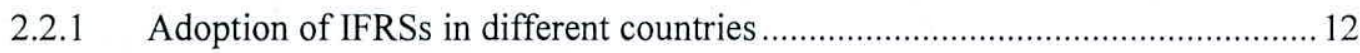

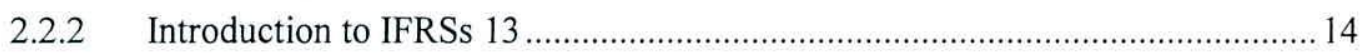

2.2.3 IFRS 13 Fair Value Measurement for Real Estate Assets.................................. 16

2.2.4 IFRS 13 Fair Value Measurement: Implications for the Real Estate Sector ...... 16

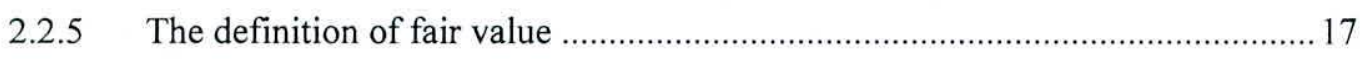

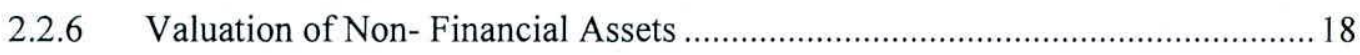

2.2.7 Compatibility of Real Estate Valuation with IFRSs 13 ...................................20

2.2.8 Appropriate valuation techniques for Real Estate Valuation ............................22

2.2.9 Applying the Fair Value Hierarchy to Real Estate Appraisals ...........................22

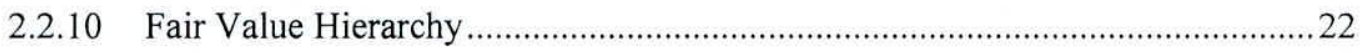

2.2.11 The Concept of Highest and Best Use for Real Estate Valuation ......................23

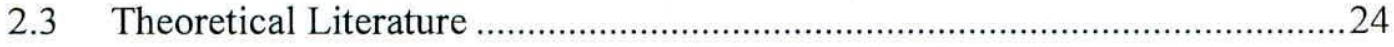

2.3.1 Attitudes, Subjective Norms, and Perceived Behavioral Control .....................24

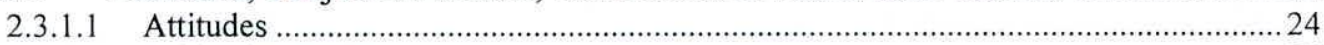

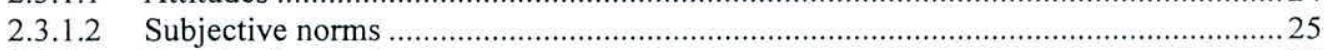

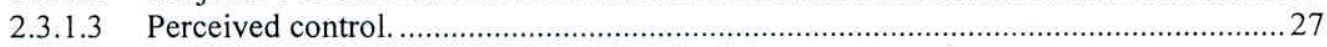

2.3.2 Firm based characteristic to adopt IFRSs ..................................................... 28 


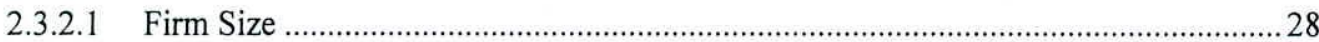

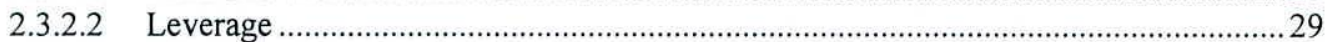

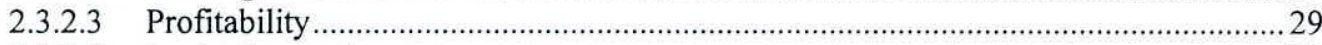

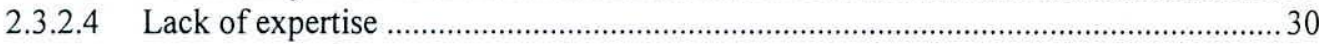

\section{CHAPTER THREE - PUBLIC LISTED COMPANIES IN SRI LANKA 31}

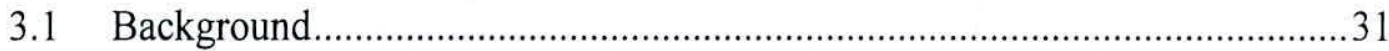

3.2 Colombo Stock Exchange (CSE) ……………………............................... 31

3.3 Publicly Listed Companies ..............................................................................

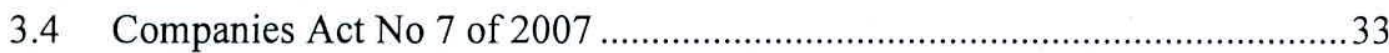

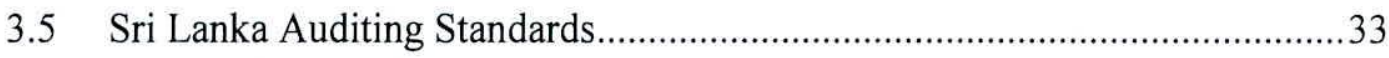

4. CHAPTER FOUR - RESEARCH DESIGN..................................................35

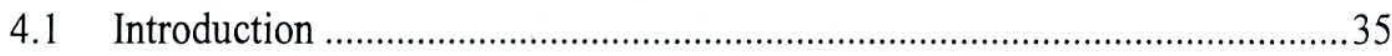

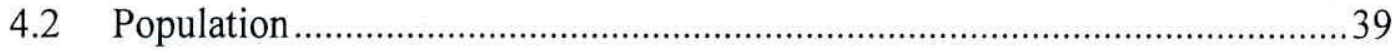

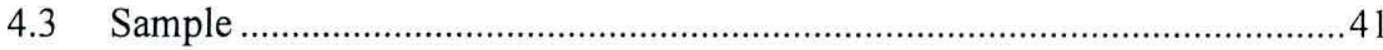

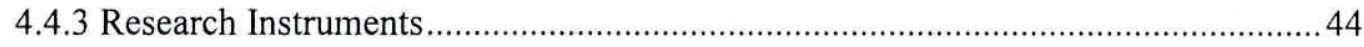

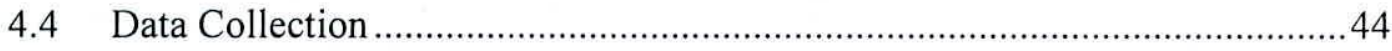

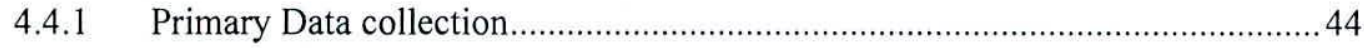

4.4.2 Factor Analysis.......................................................................................... 45

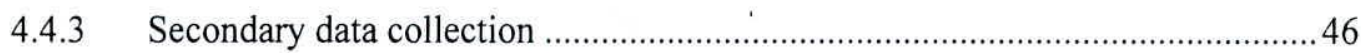

4.4.4 Validation of Measurement Properties...............................................................46

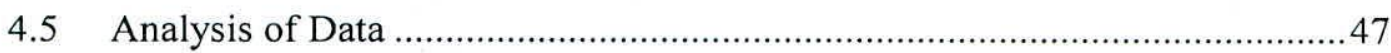

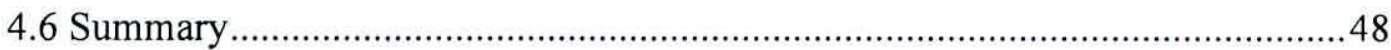

5. CHAPTER FIVE - DATA ANALYSIS ..................................................49

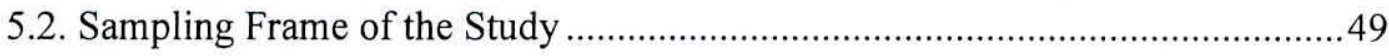

5.1.1 Data preparation for analysis......................................................................

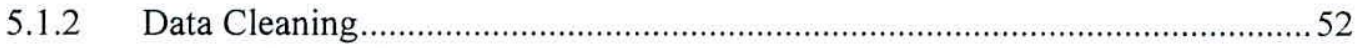

5.1.3 Tests of Normality Distribution of Data ……………………………………......52

5.1.4 The Measurement Model ……………………………………………….......

5.2 Results of Structural Equation Modeling (SEM) ………………………........5

5.2.1 Validity and Reliability of the Measurement Model............................................56

5.2.2 Construct reliability..................................................................................... 60

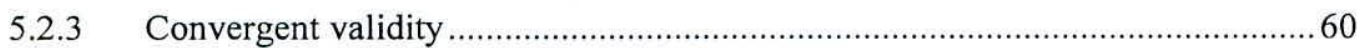




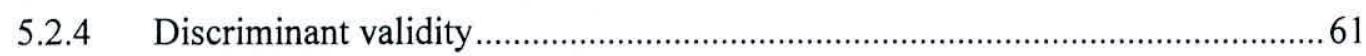

5.2.5 Assessing Collinearity issue of Formative Constructs and Indicators ................65

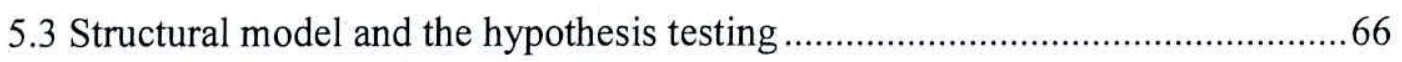

5.3 Testing for mediation effect ……….................................................... 81

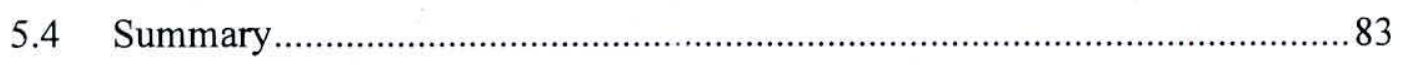

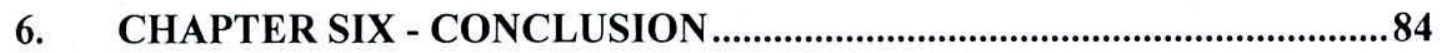

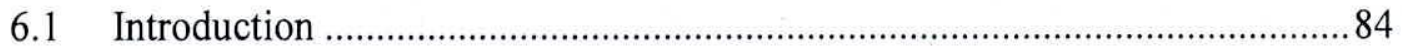

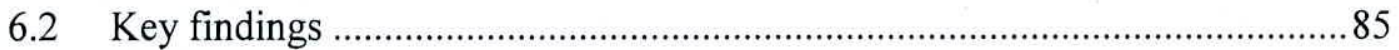

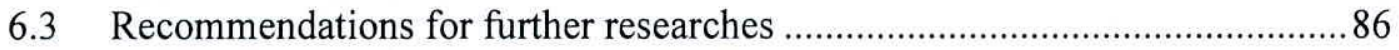

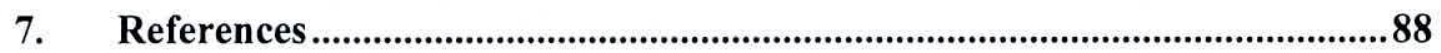

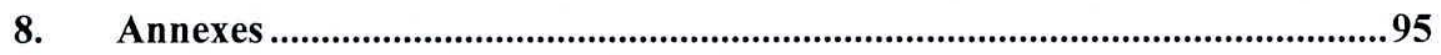

8.1 Annexure 1: Tests of Normality ....................................................................95

8.2 Annexure 2: Structural model without Attitude as a mediator ......................97

8.3 Annexure 3: Structural model without Subjective Norms as a mediator .......98

8.4 Annexure 4: Structural model without Subjective Norms as a mediator .......99

8.5 Annexure 5: Structural model without all mediators.................................... 100

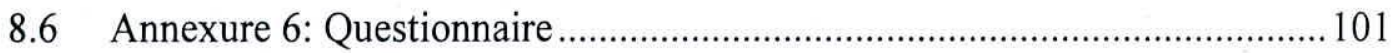




\section{LIST OF ABBREVIATIONS}

AGAA PAustralian Generally Accepted Accounting Principles

CA Chartered Accountants

CFO Chief Financial Officer

CSE Colombo Stock Exchange

EM Expectation-Maximization

EU European Union

FVA Fair Value Accounting

GAAP Generally Accepted Accounting Principles

IAASB International Auditing and Assurance Standards Board

IASB International Accounting Standard Board

IASC International Accounting Standard Committee

ICASL Institute of Charted Accountants of Sri Lanka

IFAC International Federation of Accountants

IFRSs International Financial Reporting Standards

ISA International Standards on Auditing

IVS International Valuation Standards

OLS Ordinary Least Square

PPE Property, Plant, and Equipment

PLCs Public Listed Companies

PLS Partial Least Square

REV Real Estate Valuation

ROA Return on Assets

SEC Securities Exchange Commission

SEM Structural Equation Model

SMEs Small and Medium Enterprises

TPB Theory of Planned Behavior

UK United Kingdom

USA United States of America 


\begin{abstract}
Sri Lanka adopted IFRSs with effect from $1^{\text {st }}$ January 2012 .With IFRSs gaining rapid acceptance across the globe with over a 100 countries adopting it, Sri Lanka too is now in line with the global trend in enabling a common language for financial reporting processes following the adoption of IFRSs. The Adoption of IFRSs is a major breakthrough for companies in Sri Lanka as they will have a common, high quality and internationally accepted set of accounting and financial reporting standards and is also seen as a way forward to bring in 'more credibility' to financial reporting in the country. However, there are challenges and barriers to Sri Lanka in the process of adopting IFRSs. Hence, this research was aimed to analyze Challenges and Barriers of Adopting Fair Value Accounting for Real Estate Assets Valuation in Sri Lanka Public Listed Companies. To accomplish this purpose, three objectives were developed and to achieve the objectives eighteen (18) hypotheses were formulated and tested. The first objective was to find out the major determinant factors of adopting FVA for Real Estate Valuation. That was basically achieved through a solid literature review related to the problem statement. Accordingly five firms based characteristics and three behavioral factors of managers for adopting FVA for Real Estate Valuation were identified. Second objective was formulated to identify the relationship between firms based characteristics and behavioral factors of managers for of adopting FVA for Real Estate Valuation. Accordingly fifteen hypotheses were developed on firms based characteristics in terms of Firm Size, Leverage, Profitability, Amount of Real Estate and Extent of Expertise for Fair Value Accounting. The results obtained for all fifteen hypotheses were significant. Thus, the proposed link between firms based characteristics and behavioral factors of managers for adopting FVA for Real Estate Valuation was fully supported. Third objective was to identify the relationship between behavioural factors of managers and adoptability of FVA for Real Estate Valuation in PLCs' in Sri Lanka. As per that, Attitudes, Subjective Norms, and Perceived Behavioural Control were considered as behavioural factors of managers as suggested in literature review chapter. Three hypotheses were tested and all of them were significant to confirm the proposed link between behavioural factors of managers and adoptability of FVA for Real Estate Valuation in PLCs' in Sri Lanka. The results obtained for second and third objectives, confirmed
\end{abstract}


the barriers and challenges of adopting FVA for Real Estate Valuation in Sri Lankan context.

Dependent construct of adoptability of IFRSs for Real Estate Valuation in PLCs, Perceived Control is the most influencing factor, followed by Subjective Norms and Attitudes .As far as exogenous factors: firms based characteristics and endogenous factors: behavioral factors of managers for adopting FVA for Real Estate Valuation are concerned; Extent of Expertise for Fair Value Accounting has the most significant influence on Attitudes of mangers. Level of Leverage of company determines the Perceived Control of managers in the process of Fair Value adoptability. At the same time, Firm Size has a significant impact on Subjective Norms of managers in the process respectively.

Key words: IFRSs-FVA, Real Estate Valuation, Public Listed Companies in Sri Lanka, Firm Based Characteristics, Managers' Behavioral Factors. 


\section{CHAPTER ONE-INTRODUCTION}

\subsection{Introduction}

Academics and practitioners alike are actively debating the movement toward fair value accounting, around the world including Sri Lanka. Over 100 countries have already adopted or on their way to embrace International Financial Reporting Standards (IFRSs) in the near future (Djatej, et al., 2012).

IFRSs 13 was issued by the IASB in May 2011. IFRSs 13 describes how to measure fair value under IFRSs when it is required or permitted by IFRSS. The standard does not change when an entity is required to use fair value. It also sets out certain requirements for disclosures related to fair value. As a result of the consequential amendments to other standards upon the adoption of IFRSs 13, the current requirements in IAS 40 for determining fair value will be replaced by the requirements in IFRSs 13 (Young, 2013).

Sri Lanka has already adopted IFRSs for all SMEs companies. Those standards became operative for financial statements for periods beginning on or after 1 January 2012. Sri Lanka has adopted all IFRSs (2011 version) as Sri Lanka Accounting Standards (SLFRSs). CA Sri Lanka expects those new and amended IFRSs that are effective after 2011 to become effective in 2015; however, adoption dates are yet to be finalized. Further, Sri Lanka made some modifications in adopting several IFRSs (IFRSs, 2013).

The challenge for any entity is to produce financial statements with disclosures that are useful for decision-making (Young, 2013). IFRSs 13 Fair Value Measurement is effective for annual periods on or after 1 January 2013. IFRSs 13 establishes a single framework for fair value measurement when it is required or permitted by IFRSs(Young, 2013). 
IFRSs 13 prescribes the minimum disclosures required. It is often necessary to provide additional disclosures to explain significant transactions or unusual circumstances. In addition, accounting policy choices need to be disclosed to help the user understand the financial statements (Young, 2013).

The definition of fair value in IFRS 13 is consistent with market value as defined in International Valuation Standards (IVS). But, perhaps confusingly, it differs from the IVS definition of fair value. IFRS 13 include concepts of highest and best use, valuation premise and require application of a fair value hierarchy. Whilst, in most cases, IFRS 13 does not differ from existing practice, management does need to be aware of the conceptual differences between IFRS 13 and IVS to ensure any values used for financial reporting that are obtained from appraisals, whether external or internal, are consistent with the objective of fair value measurement in accordance with IFRS 13 A challenge for any entity is to produce financial statements with disclosures that are useful for decision-making. IFRS 13 significantly expands disclosure requirements - and the extent and nature of IFRS 13 disclosures will rely heavily on the judgment of management. (Young, 2013).

For real estate entities, the adoption of IFRS 13 could result in significant changes to processes and procedures for determining fair value and providing the required disclosures. While the requirement to determine fair value by reference to market participants is not new, the definition of fair value in IFRS 13 differs from that proposed by IVS, which are the generally accepted standards for professional appraisal practice in valuing real estate internationally. The fair value framework set out in IFRS 13 contains specific requirements relating to highest and best use, valuation premise, and principal (or most advantageous) market. This may require entities and their appraisers to re-evaluate and reconsider their methods, assumptions, processes and procedures for determining fair value (Young, 2013).

A number of characteristics of the real estate industry make it a prime candidate for early conversion to IFRSs (Robert, 2008). 